\title{
Intellectual Structure of Health Care Finance through Data Mining
}

\author{
Cheng-Kun Wang
}

\begin{abstract}
Scientometrics is applied to analyse many articles's citation data and realize the paradigm shift of different countries's health care finance system. Bibliometrics is a set of methods to quantitatively analyze scientific and technological literature. The purpose of this study is to identify the evolution of the health care finance and to reveal a description of an intellectual structure. Within each discipline, journal articles, books, and monographs fill the fundamental role of storing and distributing information. This analysis reveals a wealth of information, for example the lists of highly-cited authors, books, and articles presented here.

By analyzing 59,693 citations of 1,973 articles published in SSCI and SCI journals in the health care finance field from year 2002 to year 2011, this study maps the intellectual structure of health care finance studies and find the development of health care finance. After executing keyword analysis and tag cloud analysis," insurance", "mortality", and "developing-countries" are the emerging topics in the health care finance field. The contribution of this study is to provide important insights and implications of health care finance.
\end{abstract}

Index Terms - Finance, health care, intellectual structure, tag cloud

\section{INTRODUCTION}

Health care reform looks set to stay high on the policy-making agenda in the 1990s. Some of the reforms that were planned during the 1980s have already begun to be implemented. These include the so-called internal market programme in Britain, the move from fee-for-service to capitation payments for low-income patients of GPs in Ireland and the switch from social insurance to tax-financing in Spain. Other reforms are likely to follow elsewhere [1].

\section{THEORETICAL DEVELOPMENT}

If I have seen further, it is by standing on the shoulders of giants (Sir Issac Newton, 1645-1736). It's said "stand on the shoulders of giants (the under-box slogan of Google Scholar $\left.{ }^{\circledR}\right)$ " in which giants means the highly cited authors, papers and books. We realized that via Intellectual structure model [2] could help a novice to navigate the blue ocean of knowledge domain when the novice knows nothing.

The past decade has especially seen extensive research on health care finance. There is an area or field of health care finance, the question remains somehow unclear on how it work, and what are its prospects and needs for future

Manuscript received January 12, 2013; revised March 13, 2013.

Cheng-Kun Wang is with the Graduate School of Business and Operations Management, Chang Jung Christian University, Taiwan (e-mail:brian19.brian19@gmail.com). development.

The aim of this study is to provide health care finance researchers with a unique map to better understand health care finance related publications and to provide a systematic and objective mapping of different themes and concepts in the development of Health care finance field. This study also attempts to help identify the lintellectual structure age among different publications and confirm their status and positions in their contribution to the development of health care field.

Every discipline could be seen as a particular knowledge system that is a component of a more general knowledge system. Within each discipline, journal articles, books, and monographs fill the fundamental role of storing and distributing information. Of these three means of formal communication, journal articles are perhaps the most competitive and controversial.

Consequently, citations that appear in articles published in the journals of a particular discipline provide an objective measure of the contributions of other knowledge systems to the development and progress of that particular discipline. Citations also give a relative measure of the particular contributions of authors, articles, and journals, to the progress of a particular field of knowledge. This analysis reveals a wealth of information, for example the lists of highly-cited authors, books, and articles presented here.

\section{METHOD}

Search "health care" and "finance" related journals in SSCI and SCI journals fields. Select top ranking 1000 papers in every 5-year peroid(2002-2006, 2007-2011) in the field, and analyze 59,693 citations of 1,973 articles published in SSCI and SCI journals in the health care finance field from year 2002 to year 2011, this study maps the intellectual structure of health care finance studies. Scientometrics can be a powerful research methodology for the understanding the epistemology of a field as it has evolved (and continue to evolve) by providing a historical timeline to follow up. Bibliometrics, timeline and tag cloud are applied to the study.

The tag cloud carries on the preliminary inquisition, pondered from the social network angle, uses the populace wisdom, a little at a time mounts up, or may innovate the theory and the real diagnosis, provides a new thintellectual structureing direction. The tag cloud is the common display mode for the search results in folksonomy-based websites, presenting tag sizes according to the frequency and the popularity of the key words. 
TABLE I: HistoricAl Timeline OF HEALTH CARE FinANCE DEVELOPMENT FROM CitATION ANANLYSIS (Bibliometrics). ANALYZING 38,197 CitATIONS OF TOP 1,000 ARTICLES PUBLISHED IN SSCI AND SCI JOURNALS IN THE HeAlth CARE FinANCE FIELd From YeAR 2007 TO YeAR 2011. FIVE-STAR RANKING REVEALS THE IMPORTANCE OF THE ARTICLE.

\begin{tabular}{|c|c|c|c|c|c|c|c|}
\hline $\begin{array}{l}\text { 5-star } \\
\text { ranking }\end{array}$ & Year & $\begin{array}{l}\text { Times } \\
\text { cited }\end{array}$ & $\mathrm{B} / \mathrm{J}$ & Title & & & \\
\hline$\star \star$ & 1977 & 18 & $\mathrm{~J}$ & kakwani nc & 1977 & econ $\mathrm{j}$ & v87 p71 \\
\hline$\star \star$ & 1992 & 16 & $\mathrm{~J}$ & wagstaff a & 1992 & $\begin{array}{l}\text { j health } \\
\text { econ }\end{array}$ & v11 p361 \\
\hline$\star \star$ & 1997 & 15 & $\mathrm{~J}$ & gilson 1 & 1997 & $\begin{array}{l}\text { health } \\
\text { policy } \\
\text { plann }\end{array}$ & v12 p 273 \\
\hline$\star \star \star \star \star$ & 1999 & 30 & $\mathrm{~J}$ & wagstaff a & 1999 & $\begin{array}{l}\text { j health } \\
\text { econ }\end{array}$ & v18 p263 \\
\hline $\begin{array}{l}\star \star \star \star \\
\star\end{array}$ & 2000 & 40 & B & who & 2000 & $\begin{array}{l}\text { world } \\
\text { hlth rep } \\
2000\end{array}$ & \\
\hline$\star \star$ & 2000 & 13 & $\mathrm{~J}$ & castro-leal f & 2000 & $\begin{array}{l}\text { b world } \\
\text { health } \\
\text { organ }\end{array}$ & v78 p66 \\
\hline$\star \star$ & 2001 & 15 & B & $\begin{array}{l}\text { world health } \\
\text { organization }\end{array}$ & 2001 & $\begin{array}{l}\text { macr } \\
\text { hlth inv } \\
\text { hlth e }\end{array}$ & \\
\hline$\star \star$ & 2001 & 14 & $\mathrm{~J}$ & filmer $\mathrm{d}$ & 2001 & $\begin{array}{l}\text { demogr } \\
\text { aphy }\end{array}$ & v38 p115 \\
\hline$\star \star$ & 2001 & 14 & B & $\begin{array}{l}\text { institutes of } \\
\text { medicine }\end{array}$ & 2001 & $\begin{array}{l}\text { cross } \\
\text { qual } \\
\text { chasm } \\
\text { new }\end{array}$ & \\
\hline$\star \star$ & 2002 & 17 & $\mathrm{~J}$ & ranson $\mathrm{mk}$ & 2002 & $\begin{array}{l}\text { b world } \\
\text { health } \\
\text { organ }\end{array}$ & v80 p613 \\
\hline $\begin{array}{l}\star \star \star \star \\
\star\end{array}$ & 2003 & 41 & $\mathrm{~J}$ & $\mathrm{xu} \mathrm{k}$ & 2003 & lancet & ${ }_{2}^{\mathrm{v} 36} \mathrm{p} 111$ \\
\hline$\star \star \star \star \star ~$ & 2003 & 30 & $\mathrm{~J}$ & wagstaff a & 2003 & $\begin{array}{l}\text { health } \\
\text { econ }\end{array}$ & v12 p921 \\
\hline$\star \star$ & 2004 & 17 & $\mathrm{~J}$ & ekman b & 2004 & $\begin{array}{l}\text { health } \\
\text { policy } \\
\text { plann }\end{array}$ & v19 p249 \\
\hline$\star \star$ & 2004 & 13 & $\mathrm{~J}$ & palmer $\mathrm{n}$ & 2004 & lancet & $\begin{array}{l}\text { v36 p } 136 \\
45\end{array}$ \\
\hline$\star \star$ & 2005 & 16 & $\mathrm{~J}$ & gilson 1 & 2005 & $\begin{array}{l}\text { brit med } \\
\mathrm{j}\end{array}$ & 1 \\
\hline$\star \star$ & 2005 & 13 & $\mathrm{~J}$ & carrin $g$ & 2005 & $\begin{array}{l}\text { trop } \\
\text { med int } \\
\text { health }\end{array}$ & v10 p799 \\
\hline$\star \star \star \star$ & 2006 & 25 & $\mathrm{~J}$ & $\begin{array}{l}\text { van doorslaer } \\
\text { e }\end{array}$ & 2006 & lancet & $\begin{array}{l}\text { v36 } \mathrm{p} 135 \\
87\end{array}$ \\
\hline$\star \star$ & 2006 & 20 & $\mathrm{~J}$ & mcintyre d & 2006 & $\begin{array}{l}\text { soc sci } \\
\text { med }\end{array}$ & v62 p858 \\
\hline$\star \star$ & 2006 & 14 & $\mathrm{~J}$ & borghi j & 2006 & lancet & $\begin{array}{l}\text { v36 } \mathrm{p} 145 \\
87\end{array}$ \\
\hline$\star \star$ & 2006 & 13 & B & gottret $\mathrm{p}$. & 2006 & $\begin{array}{l}\text { hlth } \\
\text { financi } \\
\text { ng revis }\end{array}$ & \\
\hline$\star \star$ & 2006 & 13 & B & $\begin{array}{l}\text { world health } \\
\text { organization }\end{array}$ & 2006 & $\begin{array}{l}\text { world } \\
\text { hlth rep } \\
2006\end{array}$ & \\
\hline$\star \star$ & 2006 & 13 & $\mathrm{~J}$ & su tt & 2006 & $\begin{array}{l}\text { b world } \\
\text { health } \\
\text { organ }\end{array}$ & v84 p21 \\
\hline$\star \star$ & 2007 & 15 & $\mathrm{~J}$ & $\begin{array}{l}\text { van doorslaer } \\
\mathrm{e}\end{array}$ & 2007 & $\begin{array}{l}\text { health } \\
\text { econ }\end{array}$ & $\mathrm{v} 16_{9}^{\mathrm{p} 115}$ \\
\hline
\end{tabular}

\section{THE FINDINGS}

After Analyzing 59,693 citations of 1,973 articles published in SSCI and SCI journals in the health care finance field from year 2002 to year 2011, highly cited authors and papers, timeline and tag cloud are found.

The detailed data includes 21,496 citations of 973 articles from year 2002 to year 2006, and 38,197 citations of 1,000 articles from year 2007 to year 2011. Some articles were highly cited and arranged in Table I, show the historical timeline of health care finance. 5-star ranking reveals the importance of the article. Some authors are in the mainstream of health care finance studies.

TABLE II: KEYWORD ANALYSIS OF 1,973 ARTICLES: "INSURANCE",

"MORTALITY", AND “DEVELOPING-COUNTRIES” BECOME MORE IMPORTANT ISSUES.

\begin{tabular}{|c|c|c|c|c|}
\hline $\begin{array}{l}\text { year } \\
2002-2006\end{array}$ & & $\begin{array}{l}\text { year } \\
2007-2011\end{array}$ & & $\begin{array}{l}\text { increased } \\
\text { importance }\end{array}$ \\
\hline Name & Frequency & Name & Frequency & \\
\hline care & 146 & care & 190 & \\
\hline health-care & 74 & health-care & 94 & \\
\hline services & 71 & services & 73 & \\
\hline united-states & 55 & insurance & 62 & important \\
\hline impact & 43 & united-states & 61 & \\
\hline health & 43 & impact & 54 & \\
\hline managed care & 41 & health & 49 & \\
\hline outcomes & 38 & countries & 46 & \\
\hline insurance & 37 & mortality & 46 & important \\
\hline access & 33 & access & 45 & \\
\hline system & 32 & quality & 43 & \\
\hline experience & 32 & equity & 35 & \\
\hline quality & 31 & outcomes & 33 & \\
\hline mortality & 30 & system & 32 & \\
\hline risk & 28 & developing-countries & 32 & important \\
\hline
\end{tabular}

\section{access ata care children chronic community controlled-trial cost-effectiveness costs countries coverage depression developing-countries disease disorders equity expenditure experience finance health health-care hospital illness impact inequalities information insurance interventions lessons management models mortality outcomes performance physicians policy poor population primary-care program quality reform risk services system therapy treatment united-states women}

Fig. 1. Tag cloud analysis on keywords of the article from 2007 to 2011:" insurance" become more important issue. 
TABLE III: CitATION ANANLYSIS (BIBLIOMETRICS). ANALYZING 38,197 CiTATIONS OF TOP 1,000 ARTICLES PUBLISHED IN SSCI AND SCI JOURNALS IN THE HEALTH CARE FINANCE FIELD FROM YEAR 2007 TO YEAR 2011. UNDERSTAND THE EPISTEMOLOGY OF A FIELD AS IT HAS EVOLVED (AND CONTINUE TO EVOlve), WAGSTAFF AND OTHER CO-AuthORS ARE ALWAYS IN THE MAINSTREAM. XU (2003), VAN DOORSLAER (2006) AND MCINTYRE (2006) JOIN THE EVOLVING TREND.

\begin{tabular}{|c|c|c|}
\hline Year 2007-2011 & Times citec & increased importance \\
\hline Author's Name and Article & Frequency & \\
\hline $\begin{array}{l}\text { xu k, 2003, lancet, v362, p111, doi } \\
10.1016 / \mathrm{s} 0140-6736(03) 13861-5\end{array}$ & 41 & increased importance \\
\hline who, 2000, world hlth rep 2000 & 40 & \\
\hline $\begin{array}{l}\text { wagstaff a, 2003, health econ, v12, } \\
\text { p921, doi } 10.1002 / \text { hec. } 776\end{array}$ & 30 & main stream \\
\hline $\begin{array}{l}\text { wagstaff a, 1999, j health econ, v18, } \\
\text { p263, doi } \\
10.1016 / \mathrm{s} 0167-6296(98) 00044-7\end{array}$ & 30 & main stream \\
\hline $\begin{array}{l}\text { van doorslaer e, 2006, lancet, v368, } \\
\text { p1357, doi } \\
10.1016 / \mathrm{s} 0140-6736(06) 69560-3\end{array}$ & 25 & increased importance \\
\hline $\begin{array}{l}\text { mcintyre d, 2006, soc sci med, v62, } \\
\text { p858, doi } \\
\text { 10.1016/j.socscimed.2005.07.001 }\end{array}$ & 20 & increased importance \\
\hline
\end{tabular}

\section{CONCLUSION}

This study investigates health care finance by analyzing 21,496 citations of 973 articles published in SSCI and SCI journals in the health care finance field from year 2002 to year 2006, and 38,197 citations of 1,000 articles published in SSCI and SCI journals in the health care finance field from year 2007 to year 2011 .

There are generally five primary methods of funding health care systems: 1.general taxation to the state, county or municipality. 2. Social health insurance. 3. Voluntary or private health insurance. 4. Out-of-pocket payments. 5. Donations to health charities. In most countries, the financing of health care services features a mix of all five models, but the exact distribution varies across countries and over time within countries. In all countries and jurisdictions, there are many topics in the politics and evidence that can influence the decision of a government, private sector business or other group to adopt a specific health policy regarding the financing structure.

In 1992, Wagstaff focuses on Equity in the finance of health care and concludes that tax-financed systems tend to be proportional or mildly progressive, that social insurance systems are regressive and that private systems are even more regressive. Out-of-pocket payments are in most countries an especially regressive means of raising health care revenues.[1] In 1997, Gilson focuses on user fee experience and found the process of policy development and implementation is an important influence over effective implementation [3]. In 1999, Wagstaff focuses on Equity in the finance of health care in some further international comparisons, and reveals taxes are a progressive means of raising revenue. Social insurance is regressive. Private insurance is regressive in countries where it is relied upon by the bulk of the population but otherwise typically progressive, reflecting the higher demand for insurance cover by the better-off. Finally, out-of-pocket payments are a highly regressive means of revenue [4].

In 2002, Ranson focuses on Reduction of catastrophic health care expenditures by a community-based health insurance scheme. The findings have implications for community-based health insurance schemes in India and elsewhere. Such schemes can protect poor households against the uncertain risk of medical expenses. They can be implemented in areas where institutional capacity is too weak to organize nationwide risk-pooling. Such schemes can cover poor people, including people and households below the poverty line [5].

In 2003, Xu focuses on Household catastrophic health expenditure. People, particularly in poor households, can be protected from catastrophic health expenditures by reducing a health system's reliance on out-of-pocket payments and providing more financial risk protection. Increase in the availability of health services is critical to improving health in poor countries, but this approach could raise the proportion of households facing catastrophic expenditure; risk protection policies would be especially important in this situation [6]. In 2003, Wagstaff focuses on Catastrophe and impoverishment in paying for health care and find that the poverty impact of out-of-pocket payments is primarily due to poor people becoming even poorer rather than the non-poor being made poor, and that it was not expenses associated with inpatient care that increased poverty but rather non-hospital expenditures [7] .

In 2006, van Doorslaer focuses on effect of payments for health care on poverty and interpret out-of-pocket health payments exacerbate poverty. Policies to reduce the number of Asians living on less than $\$ 1$ per day need to include measures to reduce such payments[8]. In 2006, McIntyre focuses on the economic consequences for households of illness and of paying for health care in low- and middle-income country contexts. Research into alternative health care financing strategies and related mechanisms for coping with the direct and indirect costs of illness is urgently required to inform the development of appropriate social policies to improve access to essential health services and break the vicious cycle between illness and poverty [9].

In 2007, van Doorslaer focuses on catastrophic payments for health care in Asia. Out-of-pocket (OOP) payments are the principal means of financing health care throughout much of Asia. They focus on payments that are catastrophic, in the sense of severely disrupting household living standards, and approximate such payments by those absorbing a large fraction of household resources. This reflect the inability of the poorest of the poor to divert resources from other basic needs and possibly the protection of the poor from user charges offered in some countries [10].

The timeline reveals the paradigm shift and evolution in health care finance development. In 1992, Wagstaff focuses on Equity in the finance of health care. In 1997, Gilson focuses on user fee experience. In 1999, Wagstaff focuses on Equity in the finance of health care in some further international comparisons. In 2002, Ranson focuses on Reduction of catastrophic health care expenditures by a community-based health insurance. In 2003, Xu focuses on Household catastrophic health expenditure. Wagstaff focuses 
on Catastrophe and impoverishment in paying for health care, and analyze the impact of out-of-pocket payments. In 2006, vans Doorslaer focuses on effect of payments for health care on poverty and interpret out-of-pocket health payments exacerbate poverty. McIntyre focuses on the economic consequences for households of illness and of paying for health care in low- and middle-income country contexts. In 2007, van Doorslaer focuses on catastrophic payments for health care in Asia.

Tag cloud analysis was used to trace the development path of health care finance research. After executing keyword analysis and tag cloud analysis of 1,973 articles in recent 10 years, " insurance", "mortality", and "developing-countries" are the emerging topics in the health care finance field. In the future, the main stream study of health care finance may focus on insurance and mortality rate.

\section{REFERENCES}

[1] A. Wagstaff and E. V. Doorslaer, "Equity in the finance of health care: Some international comparisons," J. Health Econ., vol. 11, pp. $361-387,12,1992$.

[2] H. Etemad and Y. Lee, "The knowledge network of international entrepreneurship: Theory and evidence," Small Business Economics, vol. 20 , pp. 5-23, 2003.

[3] L. Gilson, "The lessons of user fee experience in Africa," Health Policy Plan., vol. 12, pp. 273-285, 1997.

[4] A. Wagstaff, E. van Doorslaer, H. van der Burg et al., "Equity in the finance of health care: some further international comparisons," J. Health Econ., vol. 18, pp. 263-290, 6, 1999.
[5] M. K. Ransom, "Reduction of catastrophic health care expenditures by a community-based health insurance scheme in Gujarat, India: Curren experiences and challenges," Bull. World Health Organ, vol. 80, pp. 613-621, 2002.

[6] K. Xu, D. B. Evans, K. Kawabata, R. Zeramdini, J. Klavus, and C. J. L. Murray, "Household catastrophic health expenditure: a multicountry analysis," Lancet, vol. 362, pp. 111, 07/12, 2003.

[7] A. Wagstaff and E. V. Doorslaer, "Catastrophe and Impoverishment in Paying for Health Care: With Applications to Vietnam 1993-1998," Health Econ., vol. 12, pp. 921-934, 11, 2003.

[8] E. V. Doorslaer, O. O. Donnell, R. P. R. Eliya, et al., "Effect of payments for health care on poverty estimates in 11 countries in Asia: an analysis of household survey data," The Lancet, vol. 368, pp. 1357-1364, 10/14-20, 2006.

[9] D. McIntyre, M. Thiede, G. Dahlgren, and M. Whitehead, "What are the economic consequences for households of illness and of paying for health care in low- and middle-income country contexts?" Soc. Sci. Med., vol. 62, pp. 858-865, 2, 2006.

[10] E. V. Doorslaer, O. O. Donnell, R. P. R. Eliya et al., "Catastrophic payments for health care in Asia," Health Econ., vol. 16, pp. 1159-1184, 2007

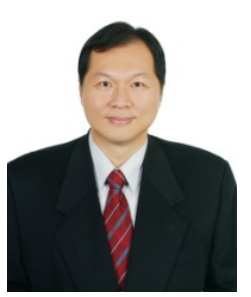

Cheng-Kun Wang is a doctoral student at the Graduate School of Business and Operations Management, Chang Jung Christian University in Taiwan. He is a medical doctor. He studied EMBA degree from the National Cheng Kung University in Taiwan. His research interests include health care and strategy. 